\title{
Efficacy of Mospilan 20 SP and Trebon 30 EC in the protection of Scots pine Pinus silvestris $L$. against the common pine sawfly Diprion pini $L$.
}

\author{
Barbara Głowacka $\bowtie$, Cezary Bystrowski \\ Forest Research Institute, Department of Forest Protection, Sękocin Stary, Braci Leśnej 3, 05-090 Raszyn, Poland, \\ phone: 4822 7150540, fax: 22 7150567, e-mail: b.glowacka@ibles.waw.pl
}

\begin{abstract}
The study was carried out to evaluate the possibilities to control the common pine sawfly Diprion pini L. with the use of plant protection products Mospilan 20 SP (20\% acetamipryd) and Trebon 30 EC (300 g etofenprox/l). Aerial insecticide treatments were applied onto experimental plots (100 ha) in Scots pine stands, sprayed with approximately 31 of spray solution/ha. Mospilan $20 \mathrm{SP}$ at a rate $0.20 \mathrm{~kg} / \mathrm{ha}$ caused $61 \%-76 \%$ mortality of $D$. pini larvae, whereas at a rate $0.25 \mathrm{~kg} / \mathrm{ha}$ $-100 \%$ larval mortality. Trebon 30 EC aerial treatments at a rate $0.21 /$ ha resulted in $100 \%$ larval mortality. Study results will be enclosed in the procedure of registration of the plant protection products for use in forestry.
\end{abstract}

\section{KeY WORDS}

Diprion pini, common pine sawfly, acetamiprid, etofenprox, aerial treatment

\section{INTRODUCTION}

Outbreaks of the common pine sawfly Diprion pini L. (Hymenoptera, Diprionidae) in pine stands have been observed in the majority of European countries, in the region of Northern Africa (Pschorn-Walcher 1982) as well as in Turkey (Tozlu 2001), the Caucasus (Supatasvili 1990) and Siberia (EPPO 2013). Pest larvae feed on Scots pine Pinus sylvestris L., and occasionally - on other pine species (Barre et al. 2002). This insect species swarms once or twice during the vegetation season (most often in April/ May and July/August). Foliage damage due to feeding larvae, and especially those of the second generation, brings about long-term reduction of wood increment as well as an increase of Scots pine susceptibility to bark beetles and eventually death of infested trees (Langstrom et al. 2001; Kurkela et al. 2005; Augustaitis 2007).

In Poland, D. pini is one of the most important leafeating pests of Scots pine, in particular in forest stands established on poor sites. In Polish subject literature, D. pini damage was reported for the first time by Brown (1902) who described pest outbreak overstressing the Młoszowskie forests owned by count A.K. Potocki (now the Forest District Krzeszowice, the Regional Directorate of State Forest Kraków). At that time, large-scale manual collection and extermination of larvae were conducted in an attempt to stop the progress of ,,pine leprosy" (then $D$. pini common name of).

In the second half of the last century, chemical treatments applied against $D$. pini initially involved 
chlorinated hydrocarbons and organophosphates. Next, there were introduced pyrethroids and later - more environment friendly insecticides from the group of chitin inhibitors. In 2009, essential law came into force in the European Union based on the Regulation (EC) No 1107/2009 of the European Parliament and of the Council of 21 October 2009 concerning the placing of plant protection products on the market and the Directive 2009/128/EC of the European Parliament and of the Council of 21 October 2009 establishing a framework for Community action to achieve the sustainable use of pesticides. As a consequence, the majority of then applied pesticides was withdrawn from the market. At the same time, there was excluded a large number of plant protection products used before in Poland's forestry, hence now for $D$. pini control there is registered only one product - Dimilin 480 SC. In view of the above, the Department of Forest Protection at the Forest Research Institute has undertaken studies on efficacy of insecticides authorized in the EU for use in plant protection with the aim to register them for use in Poland's forests.

The active substance in the plant protection product Mospilan 20 SP is acetamiprid - a neonicotinoid with of a broad-spectrum insecticidal properties against pest insects from several orders (Lepidoptera, Hymenoptera, Hemiptera and Diptera). Neonicotinoids are advantageous for their insecticidal systemic activity, i.e. they are absorbed by plants through leaves or roots and translocated all the way through the vascular system, e.g. up to young developing leaves. Mospilan $20 \mathrm{SP}$ is water soluble powder, systemic, contact and stomach insecticide for control of sucking and chewing insects in agricultural and horticultural crops as well as in orchards and forests.

Etofenprox - the active substance in Trebon 30 EC - belongs to the group of aryl propyl ethers. This is a component of insecticides applied to control aphids and Lepidoptera caterpillars feeding on foliage of orchard, agricultural and horticultural crops. It is also recommended for control of mosquitoes in wetland areas or else impregnation of mosquito-curtains. Trebon $30 \mathrm{EC}$ is formulated as concentrated emulsion soluble in water, which acts on insect nervous system through contact and digestion. This insecticide is not absorbed by plant tissues.

The active substances of both above products are authorized for use in plant protection in the EU. The aim of the present study was to evaluate efficacy of Mospilan 20 SP and Trebon 30 EC tested at different rates so as to be able to register the products and their fixed rates for use in the protection of Poland's forests against $D$. pini.

\section{MATERIAL AND METHODS}

The study was carried out in accordance with the General Principles of Good Experimental Practices, following European Plant Protection Organization (EPPO) guidelines. The insecticides were applied by means of aircraft equipment onto experimental plots selected in Scots pine stands (tab. 1).

Mospilan 20 SP (Nippon Soda Ltd.) was tested to examine its efficacy against $D$. pini larvae in the Forest Districts Cierpiszewo and Solec Kujawski (Regional Directorate of State Forests Toruń) in the year 2011. Trebon 30 EC (Mitsui Chemicals Agro Inc.) was tested in the Forest District Złoczew (Regional Directorate of State Forests Łódź) in 2014. The study areas were selected based on information on D. pini threat provided in the annual reports titled „Short-Term Forecast of the Incidence of Important Insect Pests and Infectious Diseases of Forest Trees in Poland" (for the years 2011 and 2014).

In the years 2011 and 2014, in the second half of May, in the Forest Districts Cierpiszewo and Złoczew, respectively, in Scots pine stands threatened by $D$. pini, there were felled trees onto the sheet $(4 \times 5 \mathrm{~m})$. Next, pest eggs and emerging $1^{\text {st }}$ generation larvae were counted in the crowns of the trees. Based on the results of examination, there were selected experimental plots for insecticide spray treatments. In the forest District Solec Kujawski the assessment of $D$. pini threat (tree felling on the sheet) was conducted on the first days of August 2011. Then insecticide treatments were applied to control the larvae of $2^{\text {nd }}$ generation.

The aerial treatments were performed with the use of AN-2R and Dromader M-18 aircrafts. The insecticides were applied at a rate of app. 31 of spray liquid per ha. The spray liquid consisted of the insecticide solved in 21 of water and 11 of adjuvant Ikar 95 EC. Each experimental trial comprised 3 treatments: (1) sprayed with the insecticide tested, (2) sprayed with the standard insecticide (reference), (3) unsprayed - control. Each 
treatment comprised a block of 5 experimental plots $(5 \times 20$ ha, in total -100 ha). Buffer zones (at least $200 \mathrm{~m}$ wide) were established in-between the treated areas. The treatments were applied to $1^{\text {st }}, 2^{\text {nd }}$ and $3^{\text {rd }}$ larval instars of $D$. pini.

Table 1. Characteristics of experimental plots

\begin{tabular}{|c|c|c|c|}
\hline $\begin{array}{c}\text { Forest District/ } \\
\text { Division }\end{array}$ & $\begin{array}{l}\text { Geographical } \\
\text { coordinates }\end{array}$ & $\begin{array}{c}\text { Stand } \\
\text { age } \\
\text { (years) }\end{array}$ & $\begin{array}{c}\text { Insecticide, rate/ } \\
\text { ha }\end{array}$ \\
\hline \multirow{3}{*}{$\begin{array}{l}\text { Cierpiszewo/ } \\
\text { Chojnaty/ }\end{array}$} & \multirow{3}{*}{$\begin{array}{l}52^{\circ} 59^{\prime} 29^{\prime \prime} \mathrm{N} \\
18^{\circ} 17^{\prime} 39^{\prime \prime} \mathrm{E}\end{array}$} & \multirow{3}{*}{$50-75$} & $\begin{array}{c}\text { Mospilan } 20 \mathrm{SP} \\
0.2 \mathrm{~kg} / \mathrm{ha}\end{array}$ \\
\hline & & & $\begin{array}{c}\text { Rimon } 100 \mathrm{EC} \\
0.2 \mathrm{l} / \mathrm{ha}\end{array}$ \\
\hline & & & Control \\
\hline \multirow{3}{*}{$\begin{array}{l}\text { Cierpiszewo/ } \\
\text { Grodzyna/ }\end{array}$} & \multirow{3}{*}{$\begin{array}{l}53^{\circ} 52^{\prime} 26^{\prime \prime} \mathrm{N} \\
18^{\circ} 20^{\prime} 21^{\prime \prime} \mathrm{E}\end{array}$} & \multirow{3}{*}{$55-75$} & $\begin{array}{c}\text { Mospilan } 20 \mathrm{SP} \\
0.2 \mathrm{~kg} / \mathrm{ha}\end{array}$ \\
\hline & & & $\begin{array}{c}\text { Rimon } 100 \mathrm{EC} \\
0.21 / \mathrm{ha}\end{array}$ \\
\hline & & & Control \\
\hline \multirow{3}{*}{$\begin{array}{l}\text { Solec Kujawski/ } \\
\text { Chrośnia/ }\end{array}$} & \multirow{3}{*}{$\begin{array}{l}52^{\circ} 59^{\prime} 39^{\prime \prime} \mathrm{N} \\
18^{\circ} 12^{\prime} 36^{\prime \prime} \mathrm{E}\end{array}$} & \multirow{3}{*}{$55-80$} & $\begin{array}{c}\text { Mospilan 20 SP, } \\
0.25 \mathrm{~kg} / \mathrm{ha}\end{array}$ \\
\hline & & & $\begin{array}{c}\text { Dimilin } 480 \mathrm{SC}, \\
0.1 \mathrm{l} / \mathrm{ha}\end{array}$ \\
\hline & & & Control \\
\hline \multirow{3}{*}{$\begin{array}{l}\text { Solec Kujawski/ } \\
\text { Zagórzanka/ }\end{array}$} & \multirow{3}{*}{$\begin{array}{l}53^{\circ} 03^{\prime} 48.9^{\prime \prime} \mathrm{N} \\
18^{\circ} 14^{\prime} 03.9^{\prime \prime} \mathrm{E}\end{array}$} & \multirow{3}{*}{$60-80$} & $\begin{array}{c}\text { Mospilan 20 SP. } \\
0.25 \mathrm{~kg} / \mathrm{ha}\end{array}$ \\
\hline & & & $\begin{array}{c}\text { Dimilin } 480 \mathrm{SC}, \\
0.1 \mathrm{l} / \mathrm{ha}\end{array}$ \\
\hline & & & Control \\
\hline \multirow{3}{*}{$\begin{array}{l}\text { Złoczew/ } \\
\text { Klonowa/ }\end{array}$} & \multirow{3}{*}{$\begin{array}{l}51^{\circ} 25^{\prime} 30.71 " \mathrm{~N} \\
18^{\circ} 24^{\prime} 47.16^{\prime \prime} \mathrm{E}\end{array}$} & \multirow{3}{*}{$65-100$} & $\begin{array}{c}\text { Trebon } 30 \mathrm{EC} \\
0.2 \mathrm{1} / \mathrm{ha}\end{array}$ \\
\hline & & & $\begin{array}{c}\text { Dimilin } 480 \mathrm{SC}, \\
0.15 \mathrm{l} / \mathrm{ha}\end{array}$ \\
\hline & & & Control \\
\hline
\end{tabular}

In the Forest District Cierpiszewo, Rimon 100 EC was used as the reference insecticide. Its active substance - novaluron - belongs to the group of chitin inhibitors. In the rest of the areas treated, there was used Dimilin $480 \mathrm{SC}$ with the active substance diflubenzuron (also chitin inhibitor).

On each treated, reference and control plots, right before the treatments there were selected model Scots pine trees ( 1 tree $/ 20$ ha, in total 15 trees). Under the model trees, there were placed canvas sheets $\left(1 \mathrm{~m}^{2}\right)$ for the collection of dropping down larvae, which was carried out for $2-3$ weeks after the treatment. After that, the model trees were cut down on $4 \times 5 \mathrm{~m}$ sheet and dead as well as alive $D$. pini larvae were collected from tree crowns. Pest mortality (\%) was calculated based on the results obtained for examined model trees ( 5 trees/ treatment).

For all the treatments, pest mortality assessed was corrected with Abbott's formula taking into account natural insect mortality:

$$
P=\frac{100(P o-C)}{100-C}
$$

where:

Po $-\%$ mortality observed in a given insecticide treatment,

$C-\%$ mortality in control,

$P \quad$ - mortality corrected with Abbott's formula.

The results were statistically tested with ANOVA and the Kruskal-Wallis one-way analysis of variance by ranks using Statistica 10 software (StatSoft).

\section{Results}

Table 2 presents the summary of the study results on the effect of the insecticides tested on $D$. pini larvae mortality. In two aerial treatments carried out with the use of Mospilan $20 \mathrm{SP}$ at a rate $0.2 \mathrm{~kg} / \mathrm{ha}$, there was observed pest mortality $61.4 \%$ and $76.1 \%$, respectively. At the same time, application of the reference insecticide Rimon 100 EC resulted in mortality of more than $90 \%$ of larvae. The results obtained provided no basis for starting the registration procedure to authorize Mospilan 20 SP for use in control of $D$. pini in forests. The mean values and their variability in the Forest District Cierpiszewo are presented in figures 1 and 2.

The results of two treatments performed in the Forest District Solec Kujawski showed that Mospilan 20 SP sprayed at a rate $0.25 \mathrm{~kg} /$ ha caused $100 \%$ mortality of D. pini larvae, similarly to Dimilin $480 \mathrm{SC}$, application of which caused $98 \%$ mortality of treated larvae (tab. 2, figs. 3 and 4). Aerial treatment of $D$. pini larvae with the use of Trebon $30 \mathrm{EC}$ at a rate $0.21 /$ ha carried out in the Forest District Złoczew resulted in $100 \%$ larval mortality, likewise in the case of Dimilin 480 SC treatment (tab. 2, fig. 5). 
Table 2. Mortality of $D$. pini larvae after aerial treatments of Scots pine stands with tested insecticides

\begin{tabular}{|c|c|c|c|c|c|c|}
\hline \multirow{2}{*}{$\begin{array}{c}\text { Forest District/ } \\
\text { Division/ } \\
\text { Treatment date }\end{array}$} & \multirow{2}{*}{$\begin{array}{l}\text { Experimental } \\
\text { variant }\end{array}$} & \multicolumn{3}{|c|}{ Larvae in crowns of 5 cut-down trees } & \multicolumn{2}{|c|}{$\%$ Mortality } \\
\hline & & Alive & Dead & Total & Calculated & $\begin{array}{l}\text { Corrected with } \\
\text { Abbott's formula }\end{array}$ \\
\hline \multirow{3}{*}{$\begin{array}{l}\text { Cierpiszewo/ } \\
\text { Chojnaty/ } \\
21.06 .2011\end{array}$} & $\begin{array}{l}\text { Mospilan } 20 \mathrm{SP} \\
0.2 \mathrm{~kg} / \mathrm{ha}\end{array}$ & 471 & 1019 & 1490 & 68.3 & 61.4 \\
\hline & $\begin{array}{l}\text { Rimon } 100 \mathrm{EC} \\
0.2 \mathrm{l} / \mathrm{ha}\end{array}$ & 76 & 1163 & 1239 & 93.9 & 92.5 \\
\hline & Control & 165 & 36 & 201 & 17.9 & \\
\hline \multirow{3}{*}{$\begin{array}{l}\text { Cierpiszewo/ } \\
\text { Grodzyna/ } \\
22.06 .2011\end{array}$} & $\begin{array}{l}\text { Mospilan } 20 \mathrm{SP} \\
0.2 \mathrm{~kg} / \mathrm{ha}\end{array}$ & 237 & 1061 & 1298 & 81.7 & 76.1 \\
\hline & $\begin{array}{l}\text { Rimon } 100 \text { EC } \\
0.2 \text { 1/ha }\end{array}$ & 93 & 777 & 870 & 89.3 & 86.0 \\
\hline & Control & 418 & 130 & 548 & 23.7 & \\
\hline \multirow{3}{*}{$\begin{array}{l}\text { Solec Kujawski/ } \\
\text { Chrośnia/ } \\
26.08 .2011\end{array}$} & $\begin{array}{l}\text { Mospilan } 20 \mathrm{SP} \\
0.25 \mathrm{~kg} / \mathrm{ha}\end{array}$ & 3 & 17740 & 17743 & 100.0 & 100.0 \\
\hline & $\begin{array}{l}\text { Dimilin } 480 \mathrm{SC} \\
0.1 \mathrm{l} / \mathrm{ha}\end{array}$ & 151 & 18160 & 18311 & 99.2 & 98.8 \\
\hline & Control & 3340 & 2381 & 7141 & 33.3 & \\
\hline \multirow{3}{*}{$\begin{array}{l}\text { Solec Kujawski/ } \\
\text { Zagórzanka/ } \\
27.08 .2011\end{array}$} & $\begin{array}{l}\text { Mospilan } 20 \mathrm{SP} \\
0.25 \mathrm{~kg} / \mathrm{ha}\end{array}$ & 1 & 20228 & 20229 & 100.0 & 100.0 \\
\hline & $\begin{array}{l}\text { Dimilin } 480 \mathrm{SC} \\
0.1 \mathrm{l} / \mathrm{ha}\end{array}$ & 154 & 15856 & 16010 & 99.0 & 98.5 \\
\hline & Control & 4450 & 2714 & 7164 & 37.9 & \\
\hline \multirow{3}{*}{$\begin{array}{l}\text { Złoczew/ } \\
\text { Klonowa/ } \\
6.06 .2014\end{array}$} & $\begin{array}{l}\text { Trebon } 30 \text { EC } \\
0.2 \text { 1/ha }\end{array}$ & 1 & 2807 & 2801 & 100.0 & 100.0 \\
\hline & $\begin{array}{l}\text { Dimilin } 480 \mathrm{SC} \\
0.15 \mathrm{l} / \mathrm{ha}\end{array}$ & 2 & 2760 & 2760 & 100.0 & 100.0 \\
\hline & Control & 942 & 45 & 987 & 4.6 & \\
\hline
\end{tabular}

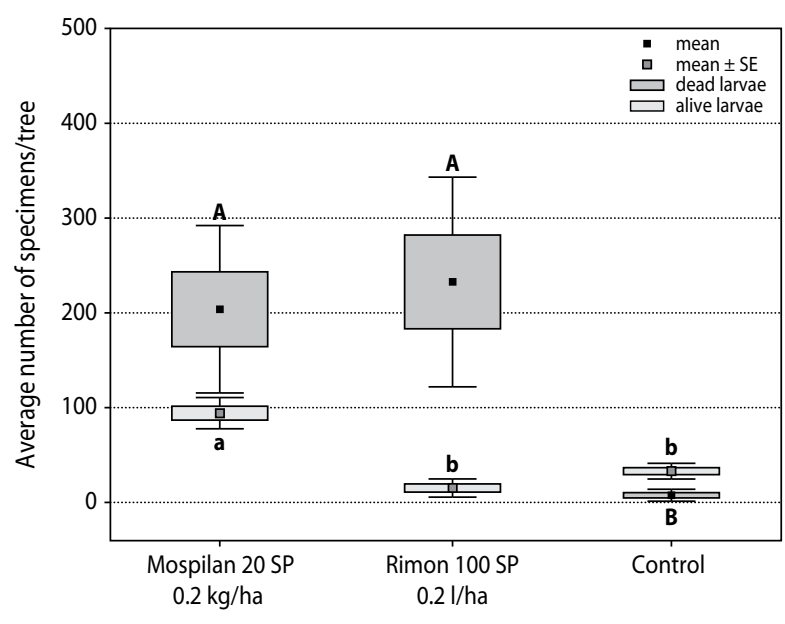

Figure 1. Mean numbers of Diprion pini on the plots treated with insecticides and on the control plot in the Forest District Cierpiszewo, Chojnaty Forest Division 


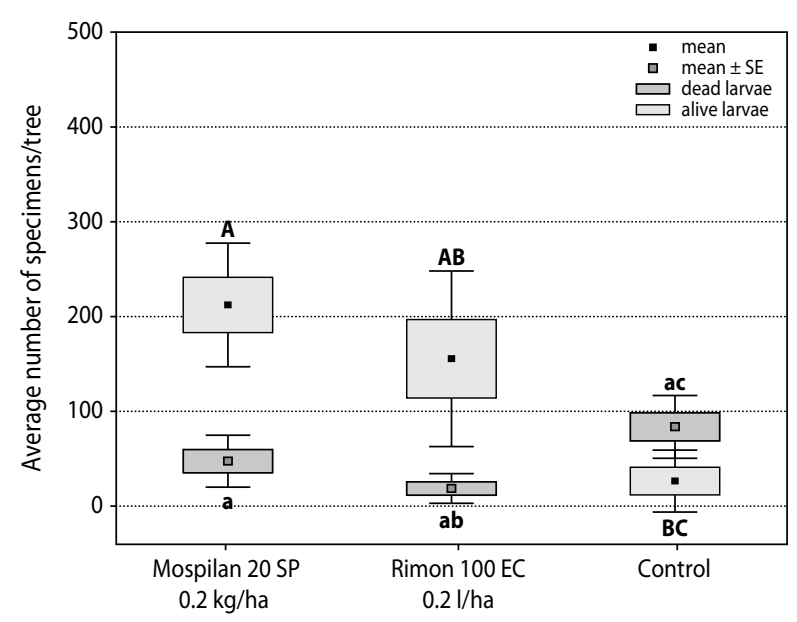

Figure 2. Mean numbers of Diprion pini on the plots treated with insecticides and on the control plot in the Forest District Cierpiszewo Forest District, Grodzyna Forest Division

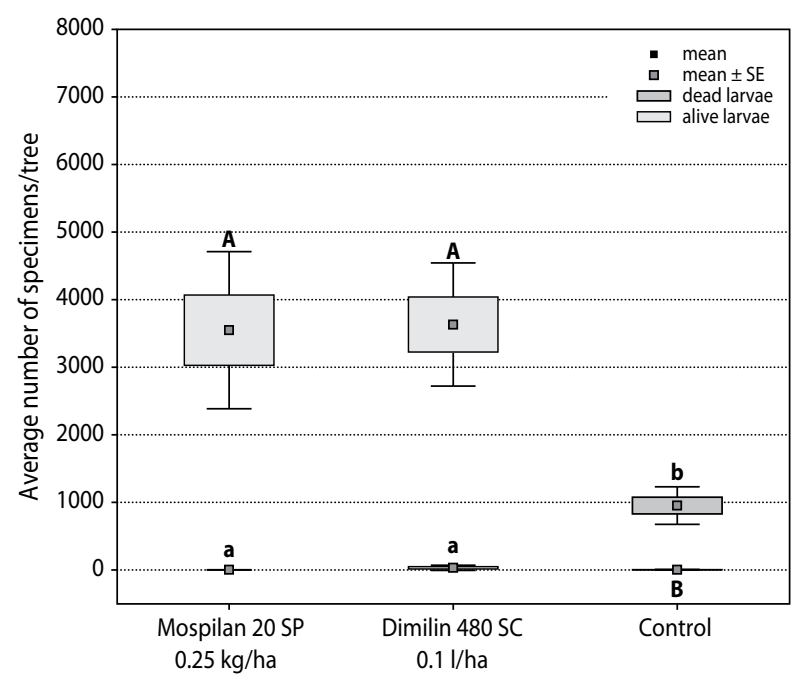

Figure 3. Mean numbers of Diprion pini on the plots treated with insecticides and on the control plot in Solec Kujawski Forest District, Chrosna Forest Division

The results presented were statistically analyzed. The number of $D$. pini larvae collected from the model trees were first tested with reference to ANOVA principles. The null-hypothesis that the numbers were normally distributed was tested with the Shapiro-Wilk test. Levene's and the Brown-Forsythe tests were used to assess the equality of variances. The data analyzed did not meet ANOVA requirements, and therefore the Kruskal-Wallis one-way analysis of variance by ranks was used for comparing independent samples. The differences between the means presented in figures are denoted with letters $a$ and $b$ (alive larvae) or A and B (dead larvae). Different letters indicate statistically significant differences. The figures were prepared with the use of Statistica 10 software.

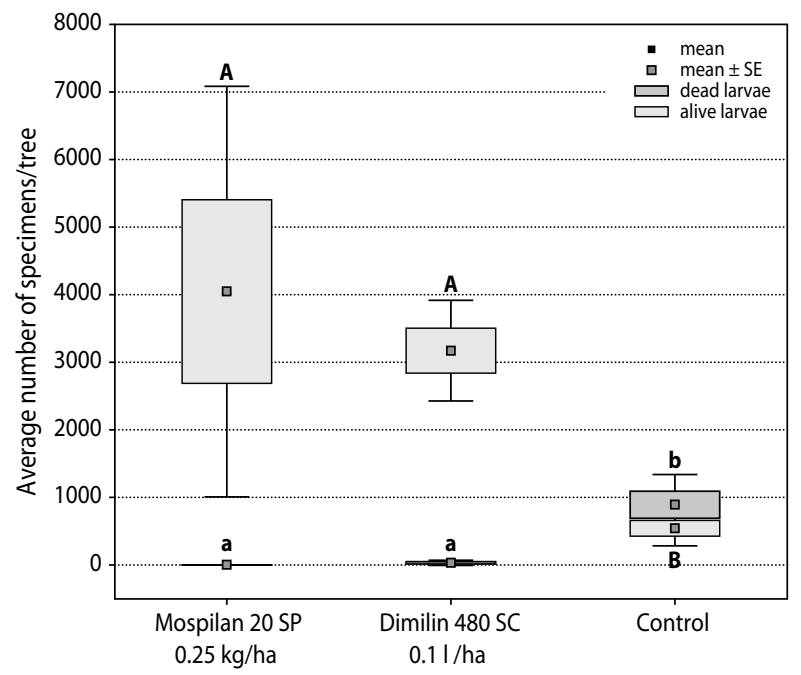

Figure 4. Mean numbers of Diprion pini on the plots treated with insecticides and on the control plot in the Forest District Solec Kujawski, Zagorzanka Forest Division

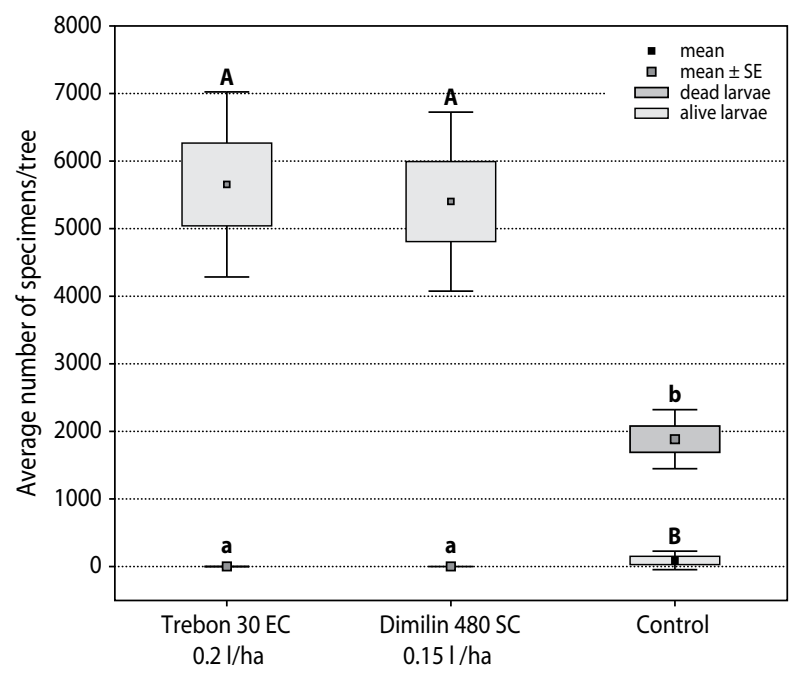

Figure 5. Mean numbers of Diprion pini on the plots treated with insecticides and on the control plot in the Forest District Zloczew Kujawski, Forest Division Klonowa 


\section{Discussion}

In natural conditions, $D$. pini population numbers are regulated mainly by parasitoids, small predatory mammals (Herz and Heitland 1999, 2003) and entomopathogenic fungi (Głowacka and Świeżyńska 1993). Nonetheless, natural enemies' activity is sometimes not as much as necessary to prevent increasing pest population and shifting from an endemic density phase into an outbreak phase. Intensive feeding of D. pini larvae leads to serious stand damages resulting in decreased tree increment, bark beetle infestation and increased tree mortality. Therefore, chemical treatments have to be applied to control pest population in Scots pine stands, and above all in those critically threatened by pest outbreak. In Poland, for last 30 years, there have been aerially treated in total 857 thousand ha of forest areas to control $D$. pini populations cyclically entering the outbreak phase (fig. 6).

In Europe, different formulations of the plant protection product Dimilin containing diflubenzuron have been so far regularly used for control of $D$. pini (Weil 1979; Winter K. 1979; Adomas 1998; Annila E. et al. 1999; Langstrom et al. 2001; Gawęda 2011). There have also been carried out studies on pest larvae sensitivity to plant-derived insecticides (Malinowski
2002) and the nuclear polyhedrosis virus (Supatasvili 1990; Skrzecz 2006), but the results obtained have not so far been applicable in forest protection practice.

Repetitive pest control treatments involving applications of unchanged insecticide result in the selection of a number of the least susceptible specimens, who always occur in abundant outbreak populations due to natural variability. As a result, some kind of pest resistance to a given insecticide can occur on a certain area. In view of that, pest control by means of insecticides with different modes of action is highly recommended.

The positive results obtained in aerial trials carried out in the present study, indicate that Mospilan 20 SP (neonicotinoid) and Trebon 30 EC (aryl propyl ether) can constitute the alternative for Dimilin 480 SC (chitin synthesis inhibitor), which has until now been the only insecticide registered in Poland for control of D. pini.

\section{Conclusions}

1. The results of the study on efficacy of Mospilan 20 SP applied in aerial treatments of Scots pine stands threatened by by Diprion pini L. showed that the insecticide at a rate $0.20 \mathrm{~kg} / \mathrm{ha}$ caused no more

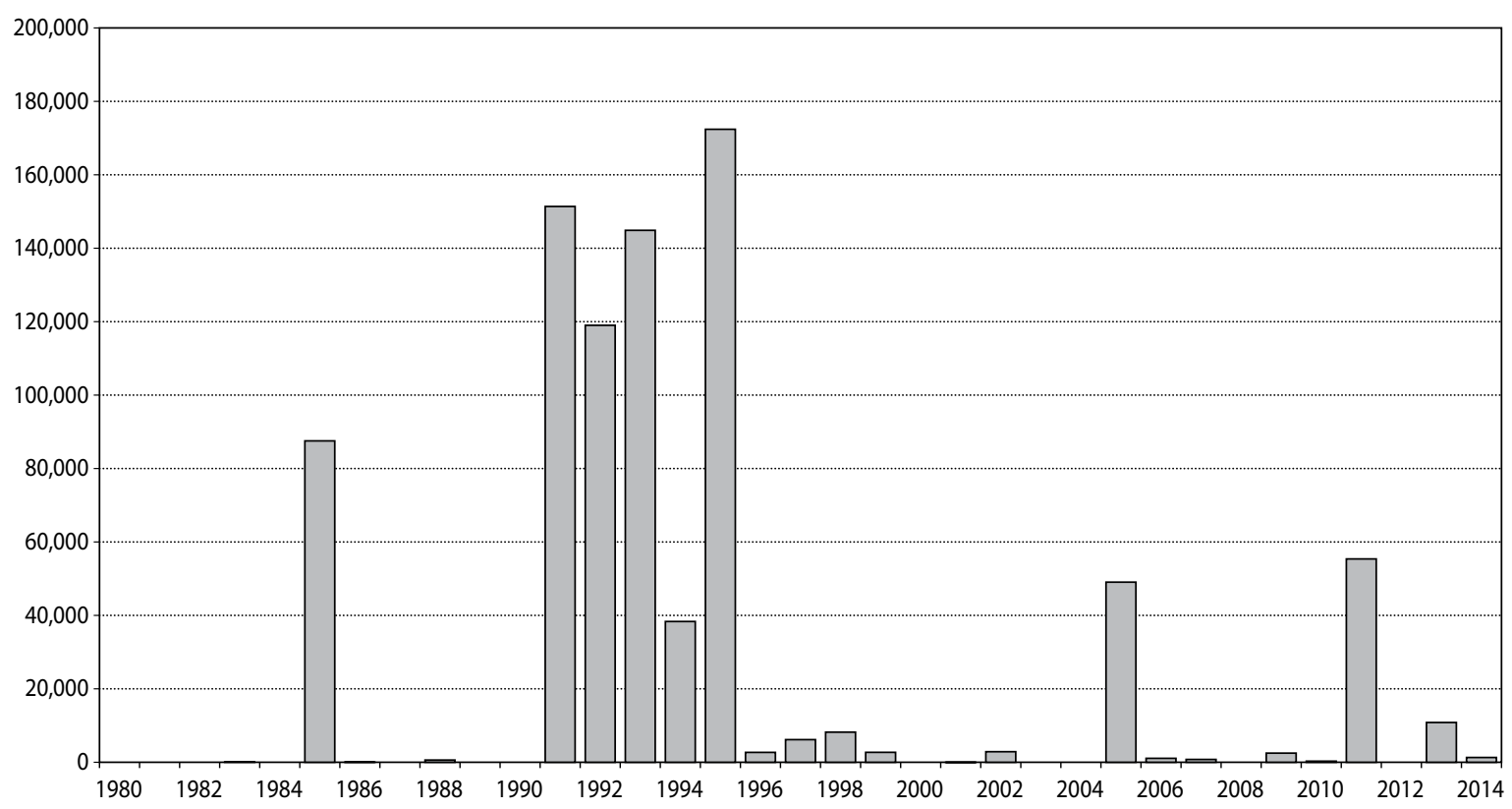

Figure 6. Control of D. pini in Poland's forests in 1980-2014 (treated area in ha) 
than $61-76 \%$ mortality of pest larvae, but when it was applied at a rate $0.25 \mathrm{~kg} / \mathrm{ha}$, larval mortality was $100 \%$. Aerial treatments with Trebon $30 \mathrm{EC}$ at a rate $0.21 /$ ha resulted in $100 \%$ larval mortality.

2. The results obtained will constitute a basis for registration of Mospilan $20 \mathrm{SP}$ at a rate $0.25 \mathrm{~kg} / \mathrm{ha}$ and Trebon $30 \mathrm{EC}$ at the rate $0.2 \mathrm{l} / \mathrm{ha}$ for the protection of Scots pine stands against D. pini.

\section{References}

Abbott W.S. 1925. A metod of computing the effectiveness of an insecticide. Journal of Economic Entomology, 18, 265-267.

Adomas J. 1998. Skuteczność preparatu Dimilin 480 SC w ochronie drzewostanów sosnowych. Progress in Plant Protection, 38 (1), 204-210.

Annila E., Långström B., Varama M., Hiukka R., Niemelä P. (1999). Susceptibility of defoliated Scots pine to spontaneous and induced attack by Tomicus piniperda and Tomicus minor. Silva Fennica, 33 (2), 93-106.

Augustaitis A. 2007. Pine Sawfly (Diprion pini L.) - Related changes in Scots pine crown defoliation and possibilities of recovery. Polish Journal of Environmental Studies, 16 (3), 363-369.

Barre F., Milsant F., Palasse C., Prigent V., Goussard F., Geri C. 2002. Preference and performance of the sawfly Diprion pini on host and non-host plants of the genus Pinus. Entomologia Experimentalis et Applicata, 102 (3), 229-237.

Brown W. 1902. Trąd Lyda pratensis (stellata) i Lophyrus (Tenthreda) pini $\mathrm{w}$ lasach powiatu chrzanowskiego. Sprostowanie - inwazya i walka przeciw niej. Sylwan, Czasopismo miesięczne dla leśników $i$ właścicieli ziemskich. Organ Galicyjskiego Towarzystwa Leśnego, 20, 113-122, 146-153.

EPPO. 2013. PQR database. Paris, France: European and Mediterranean Plant Protection Organization. http://www.eppo.int/DATABASES/pqr/pqr.htm

Gawęda P. 2011. Boreczniki - sposób postępowania w ochronie lasu. Postępy Techniki w Leśnictwie, $116,38-45$.

Głowacka B., Świeżyńska H. 1993. Grzyby owadobójcze występujące na owadach leśnych [Fungi occu- ring on forest insects]. Prace Instytutu Badawczego Leśnictwa, 767, 117-136.

Herz A., Heitland W. 1999. Larval parasitism of a forest pest, the common pine sawfly Diprion pini (L.) (Hym., Diprionidae) during an endemic density phase. Journal of Applied Entomology, 123, 129-137.

Herz A., Heitland W. 2003. Impact of cocoon predation and parasitism on endemic populations of the common pine sawfly Diprion pini (L.) (Hymenoptera, Diprionidae) in different forest types. Agricultural and Forest Entomology, 5 (1), 35-41.

Krótkoterminowa Prognoza Występowania Ważniejszych Szkodników i Chorób Infekcyjnych Drzew Leśnych w Polsce. 2011. Instytut Badawczy Leśnictwa, Analizy i Raporty, 16.

Kurkela T., Aalto T., Varama M., Jalkanen R. 2005. Defoliation by common pine sawfly (Diprion pini) and subsequent growth reduction in Scots pine: a retrospective approach. Silva Fennica, 39 (4), 467-480.

Langstrom B., Annila E., Hellquist C., Varama M., Niemela P. 2001. Tree mortality, needle biomass recovery and growth losses in Scots pine following defoliation by Diprion pini (L.) and subsequent attack by Tomicus piniperda (L.). Scandinavian Journal of Forest Resesarch, 16 (4), 342-353.

Malinowski H. 2002. Działanie azadyrachtyny na larwy boreczników (Diprionidae). Sylwan, 146 (4), $17-24$.

Pschorn-Walcher H. 1982. Symphyta. Diprionidae. In: Die Forstschadlinge Europas (ed.: W. Schwenke), Paul Parey, Hamburg, 66-129.

Skrzecz I. 2006. Bakulowirusy wybranych gatunków liściożernych owadów leśnych i ich aktywność biologiczna. Instytut Badawczy Leśnictwa, Rozprawy i Monografie, 6.

Supatasvili A.S. 1990. Biological agents controlling Diprion pini. Zascita Rastenij, 6, 23-24.

Tozlu G. 2001. Studies on the pest species belonging to the families Elateridae, Buprestidae, Cerambycidae, Curculionidae (Coleoptera) and Diprionidae (Hymenoptera) in Scotch Pine (Pinus sylvestris L.) forests of Sarikamis (Kars), Turkey. Turkiye Entomoloji Dergisi, 25 (3), 193-204. 
Weil B. 1979. Untersuchungen zur biologischen Bekamfung von Diprion pini L. In: Proceedings of international symposium of IOBC/WPRS on integrated control in agriculture and forestry, 8-12 October 1979, Vienna.
Winter K. 1979. Investigations on the effects of Dimilin on insects and spiders of the soil surface in pine forests. Mitteilungen aus der Biologischen Bundesanstalt fur Land und Forstwirtschaft, 191, 228-229. 